\title{
Analysis of Mental Health Status and Influencing Factors of Overseas Chinese in Laos
}

\section{Yanfang Li (D 421030182@qq.com)}

Fourth Military Medical University

\section{Qin Tao}

Fourth Military Medical University

Xiaoyu Zhou

Fourth Military Medical University

Kan Zhang

Fourth Military Medical University

\section{Research article}

Keywords: PHQ-9, GAD-7, foreign aid medical treatment, mental health

Posted Date: October 5th, 2020

DOI: https://doi.org/10.21203/rs.3.rs-76608/v1

License: (a) (i) This work is licensed under a Creative Commons Attribution 4.0 International License. Read Full License 


\section{Abstract}

Background: To provide a reference for foreign aid workers by identifying the mental health status of Overseas Chinese resident in Laos and the influencing factors.

Methods :Convenience sampling method was used to select the 414 Overseas Chinese in Laos from April 10 to May 10 in 2020. The mental health status was assessed by using PHQ-9 and GAD-7 scales, and the influencing factors were analyzed.

Results : The prevalence of anxiety and depression among overseas Chinese in Laos was $28.5 \%$ and $36.2 \%$. Factors influencing anxiety and depression included family members' attitudes towards their departure abroad, financial aid subsidies, living standards in Laos, and Laotian food.

Conclusion :Degrees of anxiety and depressive were varying among Overseas Chinese in Laos. Depression was highly correlated with anxiety, and the influencing factors of anxiety and depression were different. Foreign aid workers should pay attention to the mental health of the Overseas Chinese in Laos and the influencing factors.

\section{Background}

The "One Belt and One Road" is the main framework for mutually beneficial cooperation between China and southeast Asian countries, as well as an important guarantee for the economic and social development of China and countries along the belt and road. In order to better implement the "One Belt And One Road" measures, in recent years, China has sent more and more citizens to Laos for construction assistance in the political, economic, military, cultural, health and other fields. Chinese citizens have been living in Laos which is quite different from Chinese culture and which has a relatively backward economic conditions for a long time. They need to face multiple challenges in life and work, and are prone to CROSS-culture stress, which often leads to physical, psychological, behavioral and other health problems[1],In order to expand the scope of medical and health services, we should not only pay attention to the mental health of foreign medical personnel[2-7], but also should pay more attention to mental health status and influencing factors of overseas Chinese in order to provide reference basis for later foreign aid work, so this cross-sectional survey is carried out.

\section{Methods}

\section{Study Subjects}

The convenience sampling method was adopted to investigate overseas Chinese over 18 years old who were studying and working in Laos on April 10 to May 10, 2020. All the respondents volunteered to participate in the survey.

\section{Survey tool and scoring method}

Generalized Anxiety Disorder-7 (GAD-7) and Patient Health Questionnaire-9 (PHQ-9)[8] . Evaluation criteria[9-10]: 0 (not at all) 3 (almost every day); GAD-7 rating criteria: a score of 0-4 for no anxiety, a score of 5-9 for mild anxiety, a score of 10-14 for moderate anxiety, and over 15 for severe anxiety. PHQ-9 rating criteria: 0-4 points for no depression, 5-9 points for mild depression, 10-14 points for moderate depression, 15-19 points for 
moderate and severe depression, and 20-27 points for severe depression. The total score ranges from 0 to 27 points. A higher score indicates more severe symptoms of anxiety and depression.

\section{Data processing and analysis}

SPSS 18.0 software was used to sort out and analyze the survey data.

\section{Results}

\section{Baseline characteristics}

Based on the sample estimation methods that the number of observations at least 10 times the number of variables in the multivariate analysis $\mathbb{1 1} \mathrm{Q}$, there are 35 independent variables in the study. Considering the $10 \%$ invalid questionnaire rate, no less than 385 samples should be required. In fact, 433 questionnaires were collected, and 19 people (under 18 years old and the subjects were not in Laos) were excluded according to the inclusion criteria. There were 414 valid questionnaires with an effective rate of $95.6 \%$.

\section{Demographic characteristics}

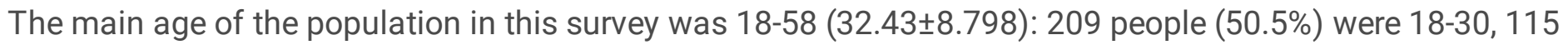
people (27.8\%) were $31-40,79$ people (19.1\%) were $41-50$ and 11 people $(2.7 \%)$ were $>50$. Gender: 100 females (24.2\%) and 314 males (75.8\%); Education level: 100 (24.2\%) were in senior high school or below, 107 (25.8\%) were in junior college, 186 (44.9\%) were in university and 21 (5.1\%) were in postgraduate or above. Occupations: 101 were administrative personnel (24.4\%), 97 were professional technical personnel (23.4\%), 83 were workers (20.0\%), 16 were sales and service personnel (3.9\%), 25 were international students (6.0\%), 18 were private owners (4.3\%) and 74 were other occupations (17.8\%); Marital status: 224 were married (54.1\%) and 190 were unmarried (45.9\%).

Demographic characteristics show that the majority were young men under the age of 30, generally higher level of education, and their occupations are mainly administrative personnel, professional technical personnel and workers, etc. Their occupations are relatively dispersed, without concentration or deviation from a certain occupation.

\section{Relevant situation in Laos}

The time of visits to Laos: 130 (31.4\%) went on the first visit, 48 (11.6\%) went on the second visit and 236 $(57.0 \%)$ went on the third visit; Time in Laos: 189 (45.7\%) were less than 3 months, 74 (17.9\%) were between 3 and 6 months, 56 (13.5\%) were between 6 and 12 months and 95 (22.9\%) were greater than 12 months; Satisfaction degree of foreign financial aid: 182 (44.0\%) were satisfied, 74 (17.9\%) were dissatisfied and 158 (38.2\%) were not clear. The material living standards and daily needs in Laos: 98 were very satisfied (23.7\%), 277 were meet basic satisfaction (66.9\%) and 39 were not satisfied (9.4\%). Dietary status: 227 (54.8\%) were satisfied, 31 (7.5\%) were dissatisfied and 156 (37.7\%) were general. Their family's attitudes towards Laos: 319 were support (77.1\%), 59 were not support (14.3\%) and 36 were not care $(8.7 \%)$

According to the survey data, most of the overseas Chinese have been to Laos for several times and their time in abroad is relatively short. The material standard of living in Laos can basically meet their daily needs. Most 
of their families support them going to Laos and $38.2 \%$ of them are not aware of the foreign financial aid.

\section{Mental Health Status (Table 1)}

5 points were selected as the cutoff point of total GAD-7 and PHQ-9 scores, and the incidence of anxiety was $28.5 \%$, among which the incidence of mild, moderate and severe anxiety was $20.5 \%, 3.9 \%$ and $4.1 \%$ respectively. The incidence of depression was $36.2 \%$, which was $23.9 \%, 6.3 \%, 3.4 \%$ and $2.7 \%$ respectively, in mild, moderate, moderate-to-severe and severe cases. After the measurement data were tested by normality test, Spearman rank correlation analysis was used to find that the correlation coefficient between GAD 7 anxiety score and PHQ-9 depression score was $0.754(\mathrm{P}<0.001)$, indicating that there was a high positive correlation between depression and anxiety in Overseas Chinese in Laos.

\section{Influencing factors of mental health status (Table 2, 3, 4)}

Influence factors analysis of anxiety and depression make anxiety ( $0=$ no, $1=$ yes) and depression ( $0=$ no, $1=$ yes) as the dependent variable, the possible influence factors as independent variables. Nonconditional binary logistic regression method was used for single factor analysis one by one and independent variable with statistical significance $(p<0.05)$ will make further multivariate analysis. Nonconditioned binary classification logistic regression was used for multivariate analysis and Omnibus method was used to test the overall effectiveness of logistic regression fitting model. When regress fitting equation, the forward stepwise LR regression in the stepwise method ( $=0.05$ as the inclusion criterion and $=0.10$ as the exclusion criterion) was used for analysis.

The single factor analysis results showed that the factors affecting the anxiety and depression of overseas Chinese included gender, family's attitude towards going abroad, foreign financial subsidies, local material living standard and diet in Laos.

The multivariate analysis results showed that the satisfaction with foreign financial subsidies $($ Wald $=12.359$, $p=0.002)$ and the satisfaction with diet (Wald $=14.217, p=0.001)$ were the main factors for the incidence of depression among overseas Chinese in Laos. The differences between the comparison groups were statistically significant. The material living standard (Wald $=47.546, \mathrm{P}<0.01$ ) and family support for going to Laos (Wald $=10.321, P=0.006)$ were the main factors affecting the anxiety of overseas Chinese. There were significant differences between the two comparison groups.

\section{Discussion}

In order to make foreign aid work more detailed, better and more standardized, combined with the influence factors of mental health, the author suggested that (1) Information disclosure: dispatched units should inform relevant self-protection knowledge and economic subsidy policies of foreign aid to foreign Chinese timely and in public, make them know fairly well and avoid the depression and anxiety due to entertain foolish ideas. (2) Economic support: in order to solve the problems of overseas Chinese, the dispatched units should in accordance with the relevant provisions of the documents or the contract and provide living allowances timely. If conditions permit, raise the standard of overseas allowances. (3) Emotional support: dispatched units or foreign authorities should pay more attention to the mental health status of overseas Chinese and attach great importance to the influence factors of overseas Chinese. For overseas Chinese dispatched to carry out missions, 
they mostly worry about their family. Dispatched units should dispatch staff to solve family difficulties, eliminating the worries of the overseas Chinese. At the same time, we suggest the dispatched units conduct mental health investigation on the dispatched personnel, someone who has a serious psychological problem such as anxiety and depression should not be sent abroad. (4) Strengthen the establishment of psychological monitoring system. Add the psychological status of overseas Chinese into the system, establish a scientific long-term mechanism of psychological crisis and organize a professional psychological intervention team. For the overseas Chinese who have psychological problems, we should take different intervention content and methods to help them make psychological adjustment timely.

\section{Conclusion}

Gad-7 and PHQ-9 have simple contents and strong operability. They have been verified by domestic and foreign studies with good reliability and validity[12-18], and widely used in a variety of research. In the next step, the author will continue to study the deficiencies in this survey, analyze and summarize the problems and experiences in the process of foreign aid. To provide reference for dispatched units to understand the mental health of foreign aid personnel, attach importance to relevant influencing factors, and formulate targeted foreign aid management measures and humanistic care measures.

\section{Abbreviations}

GAD

Generalized Anxiety Disorder ; PHQ:Patient Health Questionnaire

\section{Declarations}

\section{Authors' contributions}

YL designed survey ,drafted the manuscript and interpreted date;XZ performed the survey and revised the manuscript $\rrbracket$

QT performed literature review, date analysis $\square$ improved data interpretation ; KZ critically reviewed and improved the manuscript;All authors substantially contributed to the study and approved its submission.

\section{Funding}

This study receives no funding or financial support.

\section{Availability of data and materials}

The datasets used and/or analyzed during the current study are available from the corresponding author on reasonable request.

\section{Ethics approval and consent to participate}

This study was approved by the Ethics Committee of Xijing Hospital.All the written consents were signed voluntarily and obtained online by all adult subjects. 


\section{Consent for publication}

Not applicable

\section{Competing interests}

The authors declare that they have no competing interests.

\section{Author detsails}

${ }^{1}$ Department of Nursing ,Xijing hospital ,Fourth Military Medical University, No.127Changle West Rd,,Xi'an 710032,Shaanxi,china

${ }^{2}$ Xijing hospital ,Fourth Military Medical University,Xi'an,China

\section{References}

1. Yu Bin, Chen Xinguang.Li in October. Globalization and transliteration stress and its impact on health [J]. Chinese journal of epidemiology, 2014,35 (3) : 338-341.

2. Wang Jinlong, Yin Wenyuan, Zhang Honglong, et al.General mental health status and influencing factors of Chinese foreign medical team members [J]. Chinese journal of epidemiology,2019,40(5):574-579.

3. Liu Juan, Li Fei, Xu Zhiqiang, et al.Analysis of anxiety and depression among officers and soldiers in coastal defense training and countermeasures for mental health management [J]. Southwest China preventive medicine,2019,29(9):996-998.

4. Ling Binfang, Wu Yao, MENG Yuhua, Tian Hong, Gu Meilei, Song Xueai, Zhang Xin. Analysis of psychological symptoms of 41 African medical aid team members in the Ebola Virus Disease Treatment Center [J].Journal of nursing, 2016, 23 (3) : 71-72.

5. Zhao Mengxue, Yang Guo-yu, Yan Ling, et al.The positive and negative emotional changes of 138 soldiers who went to Liberia to fight Ebola virus disease at different stages of their missions [J].Journal of third military medical university, 2015,37 (21) :2160-2164.

6. Ling Binfang, Wu Yao, Meng Yuhua, et al.Analysis of psychological symptoms of 41 African medical aid team members in the Ebola Virus Disease Treatment center [J].Journal of nursing, 2016,23 (3):71-72.

7. Xu Ke, Zhang Sen, Zhang Li, et al.Study on mental Resilience and Influencing Factors of Nurses assisting Liberia in fighting Ebola [J].Journal of Nursing, 2017.24 (13) : 23-26.

8. Zhang Mingyuan, He Yanling, Ed. Handbook of Psychiatric Rating Scale [M].Hunan Science and Technology Press,2016

9. Schalet BD, Cook KF, Choi, et al. Lengtha common metric for self-reported anxiety: Linking the MASQ, PANAS, and GAD-7 to PROMIS anxiety [J]. J Anxiety Disord, 2014, 28(1):88-96.

10. Kroenke K, Spitzer RL, Williams JB. The PHQ-9: validity of a brief Depression Severity Measure [J]. J Gen Intern Med, 2001, 16(9): 606-13.

11. Li Zheng, Liu Yu.Nursing research methods [M].Beijing: People's Medical Publishing House, 2018.65.

12. Chang Jinghui, Yuan Yuxin, Wang Dong.Analysis of mental health status and influencing factors of College Students under coVID-19 epidemic [J/OL].Journal of Southern Medical University :1-6[2020-03-08]. 
13. Johnson Sverre Urnes, Ulvenes Pal Gunnar, $\varnothing$ ktedalen Tuva, Hoffart Asle. The Psychometric Properties of the General Anxiety Disorder - Item 7 (GAD - 7) Scale in a Heterogeneous informed Sample. [J].The Frontiers in tended, 2019, 10.

14. Liu He, Nan CAl, Ma Simeng, Zhai Yunyun, Kang Lijun, Liu Zhongchun.Correlation between event-related potential P300 and health Questionnaire -9 score and its clinical significance in patients with depression [J].Nerve injury and functional reconstruction,2020,15(02):91-94.

15. Qin Zehui. Application of PHQ-9 and GAD-7 scale in psychosocial assessment of functional gastroenteropathy [D].Youjiang Medical College for Nationalities,2019.

16. Li Jinying. Application of PHQ-9 and GAD-7 scale in psychosocial assessment of functional gastrointestinal patients [D].Guangxi Medical University,2018.

17. Xu Weifang, Peng Yi, Chen Bingquan, Peng Zhiyong, Zhao Jiling, Yu Guolong.GAD 7 and PHQ-9 Selfassessment Psychological Assessment Scales to assess anxiety and depression in outpatient department of cardiology [J].World Latest Medical Information Abstract, 2008,18(16):12-14.

18. Manea L, Gilbody S, Mcmillan D. A Diagnostic Meta-analysis of the Patient Health Chalk-9 (PHQ-9) algorithm scoring method as A screen for depression [J]. Gen Hosp Psychiatry, 2015, 37(1):67-75.

\section{Tables}

Table 1 Mental health status of depression and anxiety

\begin{tabular}{|lllll|}
\hline & \multicolumn{3}{l}{ GAD-7 } & \multicolumn{2}{l|}{ PHQ-9 } \\
& $\mathrm{N}$ & $\%$ & $\mathrm{~N}$ & $\%$ \\
\hline No depression/anxiety & 296 & 71.5 & 264 & 63.8 \\
\hline Mild depression/anxiety & 85 & 20.5 & 99 & 23.9 \\
\hline Moderate depression/anxiety & 16 & 3.9 & 26 & 6.3 \\
\hline Major depression/anxiety & 17 & 4.1 & 25 & 6.1 \\
\hline
\end{tabular}

Table 2 Lao overseas Chinese mental health effects of single factor analysis 


\begin{tabular}{|c|c|c|c|c|c|c|c|c|}
\hline Factors & Group & $\begin{array}{l}\text { Total } \\
\text { number } \\
(\%)\end{array}$ & $\begin{array}{l}\text { Positive } \\
\text { number } \\
\text { of } \\
\text { anxiety } \\
(\%)\end{array}$ & $\chi^{2}$ & $\begin{array}{l}\mathrm{P} \\
\text { values }\end{array}$ & $\begin{array}{l}\text { Positive } \\
\text { number of } \\
\text { depression } \\
\text { cases (\%) }\end{array}$ & $\chi^{2}$ & $\begin{array}{l}\mathrm{P} \\
\text { values }\end{array}$ \\
\hline \multirow[t]{4}{*}{ Age } & 18 to 30 & $\begin{array}{l}209 \\
(50.5)\end{array}$ & $\begin{array}{l}70 \\
(16.9)\end{array}$ & \multirow[t]{4}{*}{6.096} & \multirow[t]{4}{*}{0.107} & $96(23.2)$ & \multirow[t]{4}{*}{20.003} & \multirow[t]{4}{*}{$<0.01$} \\
\hline & 31 to 40 & $\begin{array}{l}115 \\
(27.8)\end{array}$ & $30(7,2)$ & & & $36(8.7)$ & & \\
\hline & 41 to 50 & $\begin{array}{l}79 \\
(19.1)\end{array}$ & $16(3.9)$ & & & $16(3.9)$ & & \\
\hline & $>50$ & $\begin{array}{l}11 \\
(2.7)\end{array}$ & $2(0.5)$ & & & $2(0.5)$ & & \\
\hline \multirow[t]{2}{*}{ Gender } & male & $\begin{array}{l}314 \\
(75.8)\end{array}$ & $\begin{array}{l}79 \\
(19.1)\end{array}$ & \multirow[t]{2}{*}{7.13} & \multirow[t]{2}{*}{0.008} & $101(24.4)$ & \multirow[t]{2}{*}{9.303} & \multirow[t]{2}{*}{0.002} \\
\hline & female & $\begin{array}{l}100 \\
(24.2)\end{array}$ & $39(9.4)$ & & & $49(11.8)$ & & \\
\hline \multirow[t]{4}{*}{$\begin{array}{l}\text { Level of } \\
\text { education }\end{array}$} & $\begin{array}{l}\text { Senior High } \\
\text { school and } \\
\text { Below }\end{array}$ & $\begin{array}{l}100 \\
(24.2)\end{array}$ & $19(4.6)$ & \multirow[t]{4}{*}{8.548} & \multirow[t]{4}{*}{0.036} & $32(7.7)$ & \multirow[t]{4}{*}{2.349} & \multirow[t]{4}{*}{0.503} \\
\hline & $\begin{array}{l}\text { Senior } \\
\text { college }\end{array}$ & $\begin{array}{l}107 \\
(25.8)\end{array}$ & $31(7.5)$ & & & $38(9.2)$ & & \\
\hline & college & $\begin{array}{l}186 \\
(44.9)\end{array}$ & $\begin{array}{l}64 \\
(15.5)\end{array}$ & & & 74 (17.9) & & \\
\hline & $\begin{array}{l}\text { Postgraduate } \\
\text { and above }\end{array}$ & $\begin{array}{l}21 \\
(5.1)\end{array}$ & $4(1.0)$ & & & $6(1.4)$ & & \\
\hline \multirow[t]{2}{*}{$\begin{array}{l}\text { Marital } \\
\text { status }\end{array}$} & married & $\begin{array}{l}224 \\
(54.1)\end{array}$ & $\begin{array}{l}56 \\
(13.5)\end{array}$ & \multirow[t]{2}{*}{2.938} & \multirow[t]{2}{*}{0.087} & $63(15.2)$ & \multirow[t]{2}{*}{13.884} & \multirow[t]{2}{*}{$<0.01$} \\
\hline & unmarried & $\begin{array}{l}190 \\
(45.9)\end{array}$ & $62(15)$ & & & $87(21.0)$ & & \\
\hline \multirow[t]{4}{*}{$\begin{array}{l}\text { Time in } \\
\text { Laos }\end{array}$} & $\begin{array}{l}\text { Less than or } \\
\text { equal to } 3 \\
\text { months }\end{array}$ & $\begin{array}{l}189 \\
(45.7)\end{array}$ & $\begin{array}{l}53 \\
(12.8)\end{array}$ & \multirow[t]{4}{*}{8.020} & \multirow[t]{4}{*}{0.046} & 74 (17.9) & \multirow[t]{4}{*}{7.386} & \multirow[t]{4}{*}{0.061} \\
\hline & 3.1-6 months & $\begin{array}{l}74 \\
(17.9)\end{array}$ & $27(6.5)$ & & & $33(8.0)$ & & \\
\hline & $\begin{array}{l}6.1-12 \\
\text { months }\end{array}$ & $\begin{array}{l}56 \\
(13.5)\end{array}$ & $20(4.8)$ & & & $18(4.3)$ & & \\
\hline & $\begin{array}{l}\text { More than } 12 \\
\text { months }\end{array}$ & $\begin{array}{l}95 \\
(22.9)\end{array}$ & $18(4.3)$ & & & $25(6.0)$ & & \\
\hline \multirow{3}{*}{$\begin{array}{l}\text { The } \\
\text { family's } \\
\text { attitude } \\
\text { towards } \\
\text { Laos }\end{array}$} & Support & $\begin{array}{l}319 \\
(77.1)\end{array}$ & $\begin{array}{l}74 \\
(17.9)\end{array}$ & \multirow[t]{3}{*}{26.263} & \multirow[t]{3}{*}{$<0.01$} & $96(23.2)$ & \multirow[t]{3}{*}{23.082} & \multirow[t]{3}{*}{$<0.01$} \\
\hline & Not support & $\begin{array}{l}59 \\
(14.3)\end{array}$ & $33(8.0)$ & & & $35(8.5)$ & & \\
\hline & Not care & 36 & $11(2.7)$ & & & $19(4.6)$ & & \\
\hline
\end{tabular}


(8.7)

\begin{tabular}{|c|c|c|c|c|c|c|c|c|}
\hline \multirow{3}{*}{$\begin{array}{l}\text { Economic } \\
\text { subsidies } \\
\text { for } \\
\text { foreign } \\
\text { aid }\end{array}$} & Satisfied & $\begin{array}{l}182 \\
(44.0)\end{array}$ & $36(8.7)$ & \multirow[t]{3}{*}{13.564} & \multirow[t]{3}{*}{0.001} & $46(11.1)$ & \multirow[t]{3}{*}{28.891} & \multirow[t]{3}{*}{$<0.01$} \\
\hline & Not satisfied & $\begin{array}{l}74 \\
(17.9)\end{array}$ & $30(7.2)$ & & & 45 (10.9) & & \\
\hline & Don't know & $\begin{array}{l}158 \\
(38.2)\end{array}$ & $\begin{array}{l}52 \\
(12.6)\end{array}$ & & & 59 (14.3) & & \\
\hline \multirow{3}{*}{$\begin{array}{l}\text { Material } \\
\text { living } \\
\text { standard } \\
\text { and daily } \\
\text { needs }\end{array}$} & $\begin{array}{l}\text { Totally } \\
\text { satisfactory }\end{array}$ & $\begin{array}{l}98 \\
(23.7)\end{array}$ & $15(3.6)$ & \multirow[t]{3}{*}{23.354} & \multirow[t]{3}{*}{$<0.01$} & $19(4.6)$ & \multirow[t]{3}{*}{25.643} & \multirow[t]{3}{*}{$<0.01$} \\
\hline & $\begin{array}{l}\text { Basically } \\
\text { satisfying }\end{array}$ & $\begin{array}{l}277 \\
(66.9)\end{array}$ & $\begin{array}{l}81 \\
(19.6)\end{array}$ & & & 106 (25.6) & & \\
\hline & $\begin{array}{l}\text { Can't } \\
\text { satisfied }\end{array}$ & $\begin{array}{l}39 \\
(9.4)\end{array}$ & $22(5.3)$ & & & $25(6.0)$ & & \\
\hline \multirow[t]{3}{*}{ Diet } & Satisfied & $\begin{array}{l}227 \\
(54.8)\end{array}$ & $\begin{array}{l}44 \\
(10.6)\end{array}$ & \multirow[t]{3}{*}{24.758} & $<0.01$ & $57(13.8)$ & \multirow[t]{3}{*}{30.42} & \multirow[t]{3}{*}{$<0.01$} \\
\hline & Not satisfied & $\begin{array}{l}31 \\
(7.5)\end{array}$ & $17(4.1)$ & & & $20(4.8)$ & & \\
\hline & General & $\begin{array}{l}156 \\
(37.7)\end{array}$ & $\begin{array}{l}57 \\
(13.8)\end{array}$ & & & 73 (17.6) & & \\
\hline
\end{tabular}

Table 3 multi-factor binary classification logistic regression analysis of anxiety

\begin{tabular}{|lllllll|}
\hline Factors & Variable & $\beta$ & $\begin{array}{l}\text { Standard } \\
\text { error }\end{array}$ & Wald & $\begin{array}{c}P \\
\text { values }\end{array}$ & $\begin{array}{l}\text { OR value } \\
(95 \% \mathrm{Cl})\end{array}$ \\
\hline $\begin{array}{l}\text { Material standard of living and } \\
\text { daily needs }\end{array}$ & $\begin{array}{l}\text { Perfectly } \\
\text { satisfying }\end{array}$ & & & 47.546 & $<$ & Reference \\
& $\begin{array}{l}\text { Basically } \\
\text { satisfying }\end{array}$ & -1.043 & 0.153 & 46.634 & 0 & $\begin{array}{l}0.352(0.261 \\
\sim 0.475)\end{array}$ \\
& Can't meet & -0.077 & 0.354 & 0.047 & 0.828 & $\begin{array}{l}0.926(0.463 \\
\sim 1.853)\end{array}$ \\
\hline $\begin{array}{l}\text { The family's attitude towards } \\
\text { Laos }\end{array}$ & Support & & & 10.321 & 0.006 & Reference \\
& Not support & 0.965 & 0.303 & 10.105 & 0.001 & $\begin{array}{l}2.624 \\
(1.447 \sim\end{array}$ \\
& Not care & 0.04 & 0.398 & 0.01 & 0.919 & $\begin{array}{l}1.041 \\
(0.477 \sim\end{array}$ \\
& & & & & & $2.271)$ \\
\hline
\end{tabular}




\begin{tabular}{|c|c|c|c|c|c|c|}
\hline Factors & Variable & $\beta$ & $\begin{array}{l}\text { Standard } \\
\text { error }\end{array}$ & Wald & $\begin{array}{l}P \\
\text { values }\end{array}$ & $\begin{array}{l}\text { OR value }(95 \% \\
\mathrm{Cl})\end{array}$ \\
\hline \multirow{3}{*}{$\begin{array}{l}\text { Economic subsidies of } \\
\text { foregin aid }\end{array}$} & Satisfied & & & 12.359 & 0.002 & Reference \\
\hline & $\begin{array}{l}\text { Not } \\
\text { satisfied }\end{array}$ & -0.389 & 0.245 & 2.51 & 0.113 & $\begin{array}{l}0.678(0.419 \sim \\
1.097)\end{array}$ \\
\hline & $\begin{array}{l}\text { Don't } \\
\text { know }\end{array}$ & 0.722 & 0.303 & 5.667 & 0.017 & $\begin{array}{l}2.058(1.136 \sim \\
3.729)\end{array}$ \\
\hline \multirow[t]{3}{*}{ Diet condition } & Satisfied & & & 14.217 & 0.001 & Reference \\
\hline & $\begin{array}{l}\text { Not } \\
\text { satisfied }\end{array}$ & 1.202 & 0.433 & 7.694 & 0.006 & $\begin{array}{l}3.325(1.423 \sim \\
7.772)\end{array}$ \\
\hline & general & 0.76 & 0.232 & 10.703 & 0.001 & $\begin{array}{l}2.138(1.356- \\
3.37)\end{array}$ \\
\hline
\end{tabular}

